\title{
Financial Factors Determining Micro-Loan Uptake by Women Enterprise Groups in Nakuru East Constituency, Nakuru County
}

\author{
Fredrick Oluoch \\ Egerton University, P.O.Box 536, Egerton \\ Dr. Fredrick M. Kalui \\ Snr Lecturer, Dpt Of Accounting \&Finance, Egerton University, P.O.Box 536 Egerton
}

\begin{abstract}
The study sought to determine financial factors determining micro-loan uptake by women enterprise groups in Nakuru East Constituency, Nakuru County. The government of Kenya acknowledging that women had been marginalized in access to formal financing, and hence introduced the Women Enterprise Fund (WEF) to provide an alternative, easily accessible and affordable finance. However despite the efforts made by the government, most women enterprises still are not accessing the funds as anticipated in this government endeavors. There has been concern among various stakeholders that even though the government has availed affordable funds for women with minimal regulatory factors, some of these funds lie idle with lenders therefore Specifically, the study sought to establish the extent to which financial characteristics, lending procedures, financial literacy and loan repayment policies affect micro-loan uptake by women enterprise groups in Nakuru East Constituency, Nakuru County. The research employed descriptive research design. The target population was 322 women groups in Nakuru Town East Constituency. Nassiuma's formula was employed to sampled 82 groups. Primary data was collected through semi structured self-administered questionnaires. Both descriptive and inferential statistics were used to analyze data. Multiple regression analysis was used as the principal data analysis method. From the study findings,financial characteristic, lending procedures, and financial literacy and loan repayment policies has a significance influence on uptake of micro-loans by women enterprise groups in Nakuru East Constituency, Nakuru County. From the finding the researcher recommended that MFIs and governments should design products specifically tailored to meet the needs of women so as to address their challenges. Women should be equipped with financial literacy skills; this can be through conducting workshops to teach these women how to start and maintain their businesses in proper financial state at all times. The study suggested that further research should be carried out to assess the effect of group dynamic on loan repayment
\end{abstract}

Key terms: Financial Factors Micro-Loan Uptake, Women Enterprise Groups

DOI: $10.7176 /$ RJFA/10-8-19

Publication date: April $30^{\text {th }} 2019$

\section{Introduction}

Micro loans refers to small-scale financial services for both, credits and deposits that is provided to people who operate small or micro enterprises, where goods are produced. Micro credit is not limited to credit and savings it also includes micro insurance and remittance services. It is seen as a basic requirement for any economic activity in the present economic condition. Micro loan is deeply concerned with the poor and those who have limited or no access to formal financial services (MIX, 2015). Microloan is a component of microfinance in that it involves providing credit to the poor, but microfinance also involves additional non-credit financial services such as savings, insurance, pensions and payment services (Okiocredit, 2015). The difference between microcredit and the subsidized rural credit programmes is that microcredit insisted on repayment, on charging interest rates that covered the cost of credit delivery and by focusing on clients who were dependent on the informal sector for credit. Micro loan uptake refers to the possibility that individuals, groups or enterprises can access financial services, including loans, deposits, payment, insurance and other risk management services. Loan uptake is the absence of price and non-price barriers in the use of financial services (World Bank, 2015). According to Beck \& Honohon (2016) those who involuntarily have no or only limited access to financial services are referred to as the unbanked. The limited access to credit has been attributed to factors such as lack of collaterals, high risk profile of SMEs, oligopolistic banking sector and biasness of SMEs by financial institutions (Gallardo et al, 2013)

\section{Micro-Loan Uptake among Women in Kenya}

In Kenya, gender equity has taken centre stage resulting in the development and enactment of various legal and policy interventions including enactment of the National Commission on Gender and Development Act in 2003 and the subsequent establishment of the National Commission on Gender and Development in November 2003; introduction of gender desks in key parastatals and police stations; introduction of the Women's Enterprise Fund; the passing of the National Policy on Gender and Development in 2006 and the 30\% Presidential decree on affirmative action in public appointments, among others. Despite these achievements, the Ministry of Planning 
and National Development Assessment Report (2005) points out the glaring gender gaps existing in access to control of resources and economic opportunities in Kenya. A survey conducted by the Kenya National Bureau of Statistics (KNBS) (2008) on the well-being in Kenya, found out that $50.8 \%$ of females are poor with $31.2 \%$ of poor households being female headed.

Additionally, the Government of Kenya recognizes the role played by the women in contributing to the economic growth and the constraints they face that limit their capacity to fully exploit their potentials in all sectors of development. Limited access to financial services has been identified by the women and the government as the one of the main limiting factors to active participation in all aspects of development. To address the needs of women and reduce the existing disparities between men and women, the government of Kenya initiated a Women Enterprise Fund (WEF) in 2006 (Republic of Kenya, 2006). The main aim of establishing WEF was to enable women access the necessary financial services to for the development of their enterprises and ultimately reduce the poverty levels.

\section{Women Enterprise Fund}

The Women Enterprise Fund was established through Legal Notice No. 147, 2007 and began its operations in December 2007. The mandate of the Fund includes providing loans to women through and the Ministry of Gender, Children \& Social Development under the Constituency Women Enterprise Scheme (C-WES). Under C-WES the clients targeted for funds channeled through the constituencies are women entrepreneurs. They are able to borrow an initial amount up to Kshs. 50,000 as a group and the group act as collateral. The group-based approach has been recognized as having the capacity to empower the most vulnerable and marginalized, especially women, by creating a community-based structure that builds mutual support and trust (Paxton, 2006). C-WES operates on this principle of group-based lending, commonly referred to as 'solidarity groups'. However, group-based models are not without their limitations.

The mandate of the Fund includes providing loans to women through and the Ministry of Gender, Children \& Social Development under the Constituency Women Enterprise Scheme (C-WES). Under C-WES the clients targeted for funds channeled through the constituencies are women entrepreneurs. They are able to borrow an initial amount up to Kshs. 50,000 as a group and the group act as collateral. However, a study by Omolo (2016) shows low uptake of C-WES services amongst women entrepreneurs in Kisumu East Constituency. The groupbased approach has been recognized as having the capacity to empower the most vulnerable and marginalized, especially women, by creating a community-based structure that builds mutual support and trust .

C-WES operates on this principle of group-based lending, commonly referred to as 'solidarity groups'. However, group-based models are not without their limitations. Mayouc (9) has raised questions regarding the extent of outreach, the limits of their ability to enforce repayments and the intensity of empowerment effects. The extent to which C-WES conditions influence the low uptake of C-WES services amongst women entrepreneurs in Nakuru East has not been investigated. Other than the conditions, C-WES has to contend with the disadvantages that women face in determining the control and access of credit.

\section{Determinants of Microloans Uptake \\ Financial Characteristics on Microloans uptake}

Bass \& Audited, (2014) financial statements are very useful in accessing credit from financial institutions because they present a picture of the financial performance of a firm. Often, creditors require audited financial statements before granting credit. When the firm is small, most of the time it is owned and operated by the entrepreneur himself and there is no such legal requirement to regularly report financial information and many firms do not maintain audited financial accounts. Audited financial statements are very useful in accessing credit from financial institutions. Often, banks require audited financial statements before granting credit. However, most of the SMEs in the South Asia have difficulty in getting credit from the formal financial institutions because they lack proper financial records. Most of the businesses in these countries often keep multiple sets of books and do not have audited financial statements based on reliable accounting standards. On the other hand, these firms end up getting loans at higher interest rates because banks considered them as high risk borrowers Combined with the absence of information on their financial records, this makes difficult to lenders to assess lending projects submitted by new firms (Pandula, 2010)

\section{Lending procedure and Microloans uptake}

Since the 1960s, larger organizations have been utilizing credit scoring to quickly and accurately assess the risk level of their prospects, applicants and existing customers mainly in the consumer lending business (Sabato, 2010). The nature of problems reported by women group was related to issues of the application process for debt finance at the banks. The main reasons for younger firms encountering problems in accessing finance related to lack of credit history. Chimucheka and Rungani (2011) sought to investigate the impact of inaccessibility of bank finance and lack of financial management knowledge to small, micro and medium enterprises (SMMEs) in the Buffalo 
City Municipality in South Africa. Findings of this research showed that SMMEs in the Buffalo City Municipality found it difficult to access bank finance. The research results also showed that inaccessibility of bank finance have a greater impact on survival and success of SMEs. Inaccessibility of finance did not have a greater impact on growth or survival of SMMEs because after SMMEs are established, they can seek other sources of finance other than bank finance.

In economic terms, the loan application process represents an investment at origination with the aim of minimizing credit losses in the future. All else being equal, a greater investment in the credit application process will result in lower subsequent rates of delinquency and default; conversely, a less stringent process would result in greater rates of credit loss in the future. (Pollinger et al, 2014). As access to loans is one of the major problems facing small scale enterprises in Nigeria. The idea of creating microfinance institutions is to provide an easy accessibility. Small scale enterprises do not have access to loans and these will bring effect on them because they will not be able to satisfy their clients (Suberu, Aremu, \& Popoola, 2014)

\section{Financial Literacy and Microloans uptake}

Financial literacy can be defined as the ways how people manage their money in terms of insuring, investing, saving and budgeting (Mahdzan \& Tabiani, 2013). Financial literacy also defined as the ability to use knowledge and skills to manage financial resources effectively for a life time of financial well-being (Suwanaphan, 2013). It also refers to a skill that can help people to make financial decisions effectively. Therefore, individuals who are financially literate are expected to possess basic understanding of the financial concepts such as interest rate, inflation rate,

In Kenya many women entrepreneurs lack financial management skills which are necessary for the access of loans. The access to credit among women in Kenya has been influenced by literacy levels. This has happened because the factor that limits women's ability to produce the sort of written business plans and loan projects that are required by lending institutions is low levels of literacy among them. They have less experience of using banks and financial services, and consequently have less knowledge and understanding of how to borrow WEF. They have little awareness of the requirements of the WEF. Lack of exposure to banking practice among women can result in a lack of confidence when it comes to making approaches for loans (Abels and Oketch, 2012). Lack of awareness on the lending procedure among women may be as a result of the financial literacy levels which this study seeks to establish among other factors.

\section{Loan Repayment Policies and Microloans uptake}

Loan repayment policies are one of the key influencers of microloan uptake. As a result of strict loan repayment policies the uptake of loans is affected since potential borrowers feel uncomfortable with the amount lent (Andrew, 2014). High interest rates on loan may discourage women from borrowing reducing the accessibility of loan among them. Some institutions have often been criticized for having high interest rates charged on loans. But sometimes, there are factors beyond their control. For example the amount of interest payable on loans depend on interest rates charged, which is driven by the base lending rate of interest set by the Central Bank of Kenya (Mole \& Namusonge, 2016). The amount of interest rate charged is affected by expected inflation, default risk, liquidity premium and maturity premium. This leads the SME's to the micro finance institution, who lend unsustainable interests short term loans (Thuranira, 2009).

As a factor affecting accessibility of loan the interest rate charged, on loans ranks high. It also affects the rate of repayment of the loans leading to high rate of default on loans. Banks have been criticized for overcharging their clients by setting high interest rates. Most of these interest rate range from $18-20 \%$. With poor business performance worsened by the global economic depression, most businesses are not only unable to repay their current loans but are discouraged from accessing more loan (Thuranira, 2009). Close monitoring of the lending institution by the central bank is required to avoid escalation of interest rates which discourages growth of the sector by reducing the accessibility of loan. The government should also increase competition in the lending sector by creating a fund exclusively for the micro finance institutions. And create a microfinance department within the central bank, instead of being lent by the commercial banks. This will enable them to borrow at competitive rates. It will enable them to; end at lower interest rates and increase available of loans as they pass the benefits to their clients (Thuranira, 2009).

\section{Government Procedures on Microloans uptake}

The function of the prevailing Government procedures is that of intervening or moderating variable whereby it acts as a buffer zone, i.e. neutral, between the independent and dependent variables of the study. Such factors include inflation and they do paly a great role in determining the relationship that exists between the independent and dependent variables of the study. Inflation refers to sustained increase in the general prices for goods and services of a country and is usually measured as a percentage change over a given period of time. Inflation tends to have a great impact on the microfinance industry since when the inflation rate is high then this implies that the 
cost of borrowing is likely to be higher hence discouraging the would borrowers. This in turn slows down the uptake of the microloans in the entire microfinance sector of the economy. On the contrary when the inflationary rates are bit low, then the cost of borrowing will most likely be low thus leading to stability in the economy thereby favoring the microfinance sector which in turn will have a positive impact on the microloans uptake since these will increase.

\section{Statement of Problem}

Women in Kenya are faced with the challenges of not accessing the funds and they appear to have less access to external sources of capital than men when securing finances. Acknowledging that women had been marginalized in access to formal financing, the government of Kenya introduced the Women Enterprise Fund (WEF) to provide an alternative, easily accessible and affordable finance. The aim of the fund was to provide affordable and reachable credit for development of women enterprises. However despite the efforts made by the government, most women enterprises still are not accessing the funds as anticipated in this government endeavors. There has been concern among various stakeholders that even though the government has availed affordable funds for women with minimal regulatory factors, some of these funds lie idle with lenders. This is an indicator that few women entrepreneurs have accessed this fund despite the fact that many potentially successful firms fail because of undercapitalization. A report compiled by Kenya Federation of Women Lawyers (FIDA) in 2014 states that the application process to obtain loan from the Constituency Women Enterprise Scheme (C-WES) was a major failure with $60 \%$ of the women groups interviewed not aware of where to get the loan application forms. In Nakuru East Constituency the uptake of women enterprise fund compared to the neighboring constituency. Several studies have been conducted on factors affecting the credit uptake however none of the studies looked at the factors determining micro loans uptake among women. This creates an area for research so as to check whether financial characteristics, lending procedures, financial literacy and repayment loan policies affect micro-loan uptake by women enterprise groups in Nakuru East Constituency, Nakuru County.

\section{Objectives of the Study}

The main objective of this study was to analyze financial factors determining micro-loan uptake by women enterprise groups in Nakuru East Constituency, Nakuru County.

\section{Specific Objectives}

i. To establish the influence of financial characteristics on micro-loan uptake by women enterprise groups in Nakuru East Constituency, Nakuru County.

ii. To examine the influence of lending procedures on micro-loan uptake by women enterprise groups in Nakuru East Constituency, Nakuru County.

iii. To assess the influence of financial literacy on micro-loan uptake by women enterprise groups in Nakuru East Constituency, Nakuru County.

iv. To find the influence of loan repayment policies on micro-loan uptake by women enterprise groups in Nakuru East Constituency, Nakuru County.

\section{Research Hypotheses}

$\mathbf{H}_{01}$ : Financial characteristics have no significant influence on micro-loan uptake by women enterprise groups in Nakuru East Constituency, Nakuru County.

H02: Lending procedures has no significant influence on micro-loan uptake by women enterprise groups in Nakuru East Constituency, Nakuru County.

$\mathbf{H}_{03}$ : Financial literacy has no significant influence on micro-loan uptake by women enterprise groups in Nakuru East Constituency, Nakuru County.

H04: Loan repayment policies have no significant influence on micro-loan uptake by women enterprise groups in Nakuru East Constituency, Nakuru County. 


\section{Conceptual Framework}

This study was guided by the following conceptual framework:

\section{Independent Variables}

Variable

\section{Financial factors}

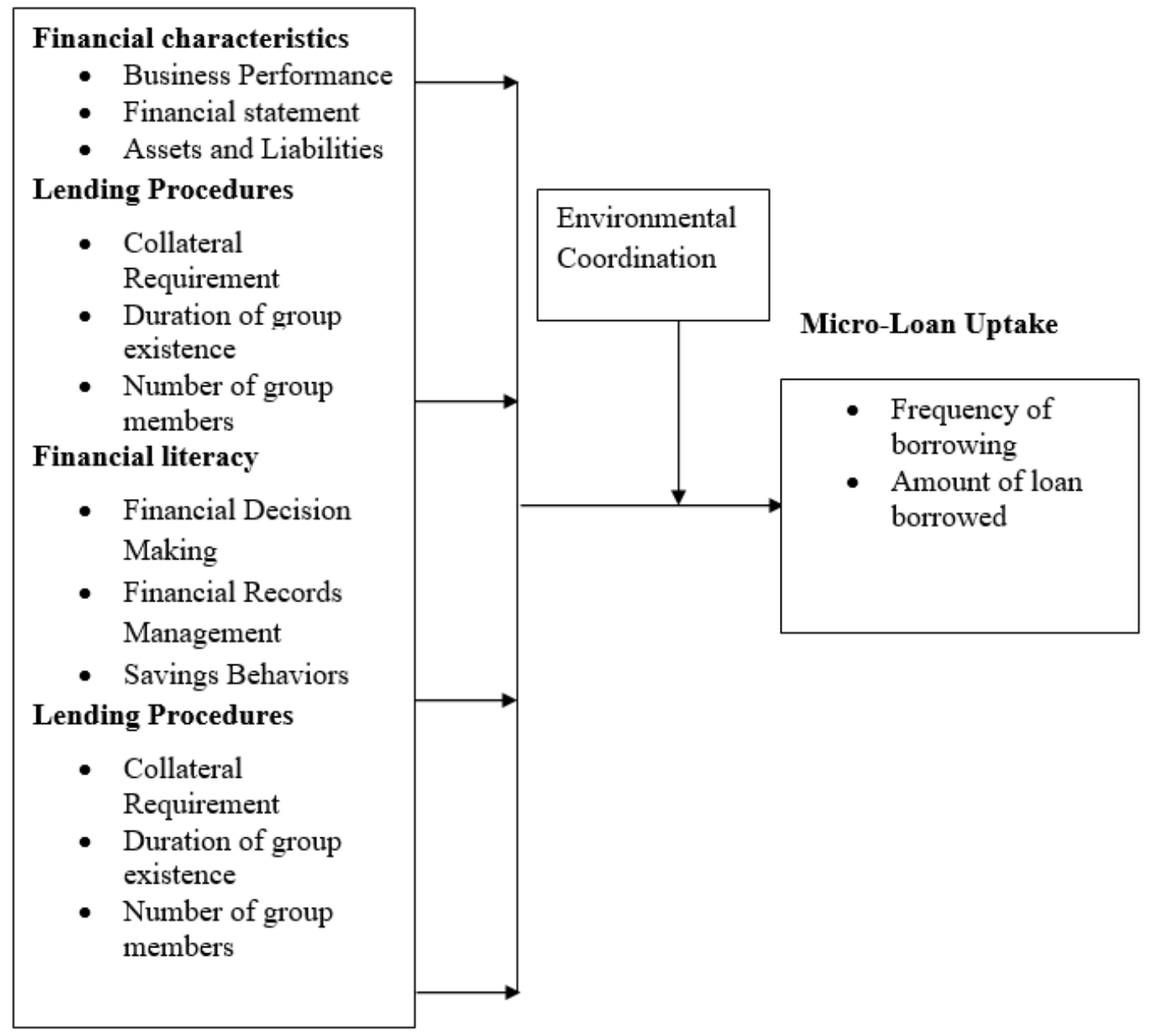

Figure 1: Conceptual Framework

\section{Source: Own Conceptualization}

This study is based on the conceptual framework depicted in the above figure and it's presumed that the independent variables which include financial characteristics, lending procedures, financial literacy and loan repayment terms do have a direct bearing on the uptake of group loans which represents the dependent variable.

\section{Research Methodology}

The research employed descriptive research design. Descriptive research design allows for gathering in-depth information that may be either quantitative or qualitative in nature. This allows for a multifaceted approach to data collection and analysis. This study made use of both quantitative and qualitative data and hence descriptive research design was to be the most suitable for this study. The target population was 322 women groups in Nakuru Town East Constituency. The unit of observation was women group chairpersons. Nassiuma's (2000) formula was employed to determine the sample size.

$$
n=\frac{N C^{2}}{C^{2}+(N-1) e^{2}}
$$

Where

$\mathrm{n}=$ Represents sample size,

$\mathrm{N}=$ Represents study population

$\mathrm{C}=$ Represents coefficient of variation $(21 \% \leq \mathrm{C} \leq 30 \%)$, and 
$\mathrm{e}=$ Represents error margin $(2 \% \leq \mathrm{e} \leq 5 \%)$.

Calculating the sample size,

$\begin{array}{llc}\mathrm{n} & = & \frac{322(0.21)^{2}}{2^{2}+(322-1)} 0.02^{2} \\ \mathrm{n} & = & 82 \\ \mathrm{n} & = & 82 \text { groups }\end{array}$

Stratified random sampling was adopted to get the sample size of women groups from each ward. Each ward was considered as a stratum. rimary data was collected through questionnaires. . The design of the questionnaire was based on a multiple-item measurement scale. A five-point Likert Scale was employed, using a list of response categories ranging from very great extent to not at all. Cronbach's Alpha was used to test reliability of instruments. Kombo \& Tromp (2009) indicates that an alpha range of 0.6 to 0.7 is commonly accepted rule of thumb that indicates good reliability. Descriptive statistics involved the use of proportions, frequencies, measures of central tendencies (mean) and measures of dispersion (standard deviation). Inferential statistics, Pearson Correlation and multiple regressions were used to test the relationship between dependent variable and independent variables.

$Y=\alpha+\beta_{1} X_{1}+\beta_{2} X_{2}+\beta_{3} X_{3}+\beta_{4} X_{4}+\varepsilon_{i}$

$\mathrm{Y}=$ Micro loan uptake

$\alpha=$ Regression constant

$\beta_{1}, \beta_{2}, \beta_{3}, \beta_{4}=$ Coefficient factors

$\mathrm{X}_{1}=$ Financial characteristics

$\mathrm{X}_{2}=$ Lending procedures

$\mathrm{X}_{3}=$ Financial Literacy

$\mathrm{X}_{4}=$ Loan repayment policies

$\varepsilon_{\mathrm{i}}=$ Error term assumed to be normally distributed

\section{Result and Discussion}

Response rate equals the number of people with whom semi-structured questionnaires were properly completed divided by the total number of people in the entire sample (Fowler, 2004). The study administered 82 questionnaires for data collection. However, only 62 questionnaires were properly filled and returned. This represented 74 percent response rates. Babbie (1990) suggested that a response rate of $50 \%$ is adequate $60 \%$ is good and $70 \%$ and above very good for analysis. This implies that 74 percent response rate was very appropriate for data analysis.

Table 1: Financial characteristics and micro-loan uptake

\begin{tabular}{|c|c|c|c|c|c|c|c|}
\hline & $\begin{array}{l}\text { SA } \\
\%\end{array}$ & $\begin{array}{l}\mathbf{A} \\
\%\end{array}$ & $\begin{array}{l}\mathbf{U} \\
\% \\
\end{array}$ & $\begin{array}{l}\mathbf{D} \\
\%\end{array}$ & $\begin{array}{l}\text { SD } \\
\% \\
\end{array}$ & Mean & Std \\
\hline The group maintains and keeps a list of their assets and liabilities. & 26 & 471 & 17 & 10 & 0 & 3.887 & 0.907 \\
\hline The group has a monthly and a yearly budget that they follow. & 23 & 173 & 3 & 35 & 22 & 2.113 & 1.270 \\
\hline $\begin{array}{l}\text { The group is in a capacity to maintain all their financial records on income anc } \\
\text { expenditure. }\end{array}$ & & 205 & 5 & 35 & 25 & 1.916 & 1.965 \\
\hline The group engage an auditor to check their financial statements & 17 & 137 & 7 & 33 & 30 & 2.600 & 1.121 \\
\hline The group must produce its financial statement before it receive loan & 39 & 441 & 11 & 6 & 0 & 4.145 & 0.866 \\
\hline The group keeps record of all the cash flow & 45 & 371 & 13 & 5 & 0 & 4.226 & 0.857 \\
\hline
\end{tabular}

According to the findings, majority of the respondents (73\%) agreed that group maintains and keeps a list of their assets and liabilities with a mean of 3.887. The findings further indicated that majority of the respondents $(57 \%)$ disagreed that the group has a monthly and a yearly budget that they follow. with a mean of 2.113 . In addition majority of the respondents $(60 \%)$ disagreed that the group is in a capacity to maintain all their financial records on income and expenditure with a mean of 1.965

The findings further indicated that majority of the respondents $(63 \%)$ disagreed that the group engage an auditor to check their financial statements with of mean 2.600 . In addition majority of the respondents $(83 \%)$ agreed that the group must produce its financial statement before it receive loan with a mean of 4.145. Finally majority of the respondents (82\%) agreed that the group keeps record of all the cash flow with a mean of 4.226. Any business must have financial characteristics that will help when applying for a loan like keeping audited financial statements or by having collateral. This help in building a strong case when applying for a loan. The study is in line with. The study further agreed with Pandula (2010) who argued that most of the women groups have difficulty in getting credit from the formal financial institutions because they lack proper financial records. Most of the businesses in these countries often keep multiple sets of books and do not have audited financial statements based on reliable accounting standards.

Lending procedures and micro-loan uptake

The respondents were asked to indicate their level of agreement on the influence of lending procedures on micro- 
loan uptake by women enterprise groups in Nakuru East Constituency, Nakuru County. The findings were as indicated in Table 4.7

Table 2: Lending procedures and micro-loan uptake

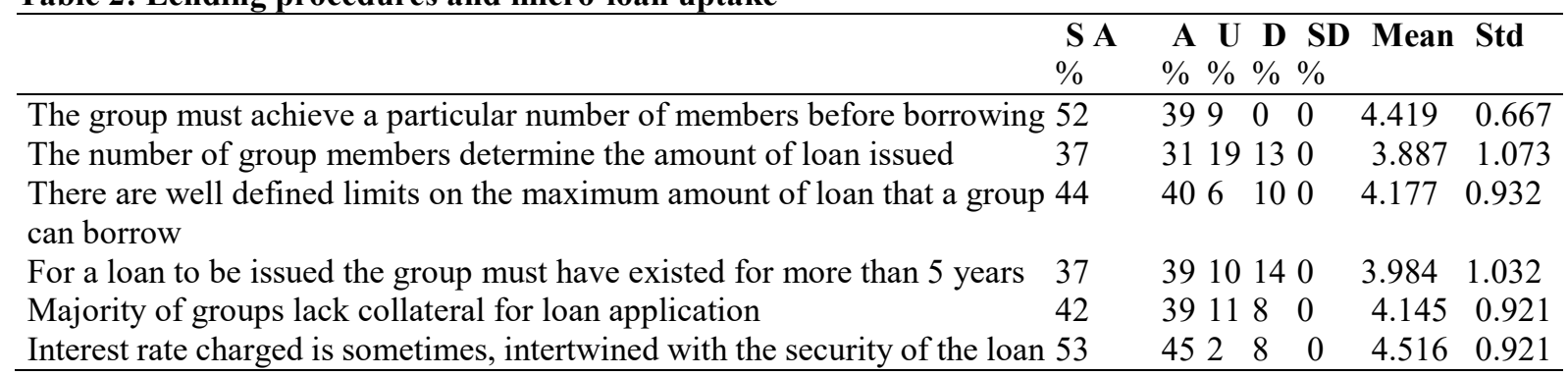

According to the findings majority of the respondents agreed (91\%) that the group must achieve a particular number of members before borrowing with a mean of 4.419 . The findings further indicated that majority of the respondents $(68 \%)$ agreed that the number of group members determine the amount of loan issued with a mean of 3.887. Also, the findings indicated that majority of the respondents $(84 \%)$ agreed that there are well defined limits on the maximum amount of loan that a group can borrow with a mean of 4.177 . Further majority of the respondents $(76 \%)$ agreed that for a loan to be issued the group must have existed for more than 5 years with a mean of 3.984. Majority of the respondents (81\%) agreed that the majority of groups lack collateral for loan application with a mean of 4.145 . Finally majority of the respondents (98\%) agreed that interest rate charged is sometimes, intertwined with the security of the loan with a mean of 4.516. The findings agree with findings by (FSB, 2006) who found that businesses less than three years old were least likely to have their application approved. Pandula (2010) argue that smaller groups have fewer assets to offer as collateral. The collateral is an assurance to the lender in case of default and it also ensures the borrowers commitment to the loan repayments. .

\section{Financial literacy and micro-loan uptake}

The respondents were asked to indicate their level of agreement on the influence of financial literacy on microloan uptake by women enterprise groups in Nakuru East Constituency, Nakuru County. The findings were as indicated in Table 4.11.

Table 4. : Financial literacy and micro-loan uptake

\begin{tabular}{|c|c|c|c|c|c|c|}
\hline & $\begin{array}{l}\mathbf{S} \\
\mathbf{A}\end{array}$ & $\begin{array}{ll}\mathbf{A} \mathbf{U} \\
\end{array}$ & $\mathbf{D}$ & SD & Mean & Std \\
\hline & $\%$ & $\% \%$ & $\%$ & $\%$ & & \\
\hline $\begin{array}{l}\text { Lack of awareness on funding opportunities has led to poor access to credit } \\
\text { by Women Group }\end{array}$ & & 3111 & 8 & 0 & 4.226 & 0.948 \\
\hline Majority of group members lack awareness of existing credit schemes & 55 & 423 & 0 & 0 & 4.516 & 0.565 \\
\hline $\begin{array}{l}\text { Majority of group members lack information on interest rates of various } \\
\text { credit schemes }\end{array}$ & & 340 & 0 & 0 & 4.645 & 0.482 \\
\hline oup members don't have information on the collateral & 52 & 480 & 0 & 0 & 4.516 & 0.504 \\
\hline $\begin{array}{l}\text { Information on availability of loans, and the rate of interests charged, is } \\
\text { adequately communicated }\end{array}$ & & 505 & 0 & 0 & 4.403 & 0.586 \\
\hline
\end{tabular}

According to the findings majority of the respondents $(81 \%)$ agreed that lack of awareness on funding opportunities has led to poor access to credit by Women Group with a mean of 4.226. Majority of the respondents $(97 \%)$ also agreed with a mean of 4.516 that majority of group members lack awareness of existing credit schemes. Majority of the respondents $(100 \%)$ further agreed indicated that majority of group members lack information on interest rates of various credit schemes with a mean of 4.645. In addition majority of the respondents $(100 \%)$ agreed that that majority of group members don't have information on the collateral with a mean of 4.516. Finally majority of the respondents (95\%) agreed that information on availability of loans, and the rate of interests charged, is adequately communicated with a mean of 4.403. Lack of Collateral security has become a constraint to young women entrepreneurs since most of them may not have deeds to capital assets to present as security against the loans hence their loans applied are rejected due to failure to produce Collateral security while others had decided not to apply since they 'knew' they would not be granted due to lack of Collateral security. According to Kamau (2009) Collateral security is again highlighted as a major constraint to credit access.

\section{Loan repayment policies and micro-loan uptake}

The respondents were asked to indicate their level of agreement on the influence of loan repayment policies on micro-loan uptake by women enterprise groups in Nakuru East Constituency, Nakuru County. The findings were as indicated in Table 4.13 
Table 5:Loan repayment policies and micro-loan uptake

\begin{tabular}{lccccccc}
\hline & $\begin{array}{l}\text { S A } \\
\text { \% }\end{array}$ & $\begin{array}{c}\mathbf{A} \\
\text { \% }\end{array}$ & $\begin{array}{l}\text { U } \\
\text { D }\end{array}$ & $\begin{array}{l}\text { SD } \\
\text { \% }\end{array}$ & Mean Std \\
\hline Group consider interest rated before borrowing & 47 & 34 & 13 & 6 & 0 & 4.210 & 0.908 \\
A less liquid security attracts high interest rate & 50 & 31 & 15 & 5 & 0 & 4.258 & 0.886 \\
Interests on loans vary depending on length of time to maturity & 44 & 53 & 3 & 0 & 0 & 4.403 & 0.557 \\
The group consider the penalties for loan default before taking loan & 37 & 44 & 16 & 3 & 0 & 4.145 & 0.807 \\
We are provided a grace period before starting to make payment for the loan 35 & 45 & 5 & 0 & 0 & 4.452 & 0.592 \\
The interest per month on loan earns and the repayment period is convenient 52 & 44 & 4 & 0 & 0 & 4.468 & 0.593 \\
to you & & & & & \\
\hline
\end{tabular}

According to the findings majority of the respondents (81\%) agreed that group consider interest rated before borrowing with a mean of 4.210 . Majority of the respondents $(81 \%)$ also agreed that a less liquid security attracts high interest rate with a mean of 4.258 . Majority of the respondents $(97 \%)$ also agreed that interests on loans vary depending on length of time to maturity with a mean of 4.403 . In addition majority of the respondents $(81 \%)$ agreed that the group consider the penalties for loan default before taking loan with a mean of 4.145. Further majority of the respondents $(80 \%)$ agreed that group are provided a grace period before starting to make payment for the loan with a mean of 4.452 . Finally majority of the respondents $(96 \%)$ agreed that the interest per month on loan earns and the repayment period is convenient to you with a mean of 4.468. According to Kamau (2009) the high interest rates, discourages the entrepreneurs in this sector from borrowing. This is because the interest payment eats into the profit and therefore reduces borrowing business if profit and trading conditions are unfavorable. The rates on interests charged discouraged the young women entrepreneurs from borrowing since they seemed punitive.

\section{Micro-loan uptake of Women Enterprise Scheme}

The respondents were asked to indicate their level of agreement on micro-loan uptake at Nakuru East Constituency Women Enterprise Scheme amongst women entrepreneurs. The findings were as indicated in Table 4.15.

Table 6 : Micro-loan uptake of Women Enterprise Scheme

\begin{tabular}{lllllllc}
\hline & $\begin{array}{l}\mathbf{S} A \\
\mathbf{A}\end{array}$ & $\begin{array}{c}\mathbf{A} \\
\mathbf{\%}\end{array}$ & $\begin{array}{c}\mathbf{U} \\
\mathbf{\%}\end{array}$ & $\begin{array}{l}\mathbf{D} \\
\mathbf{\%}\end{array}$ & $\begin{array}{c}\text { SD } \\
\%\end{array}$ & Mean & Std \\
\hline It is easier to access and cheaper to access (C-WES) loans & 10 & 16 & 37 & 34 & 3 & 2.855 & 1.385 \\
The demand for loans is high than the supply & 55 & 34 & 8 & 3 & 0 & 4.403 & 0.778 \\
Procedures for loan application and award encourages loan Uptake & 44 & 46 & 7 & 3 & 0 & 4.307 & 0.738 \\
The group is able to make full payment of loan on time & 37 & 44 & 16 & 3 & 0 & 4.145 & 0.807 \\
Group members are confident of taking up loans from (C-WES) & 55 & 33 & 7 & 5 & 0 & 4.387 & 0.869 \\
\hline
\end{tabular}

According to the findings majority of the respondents (71\%) disagreed that it is easier to access and cheaper to access (C-WES) loans with a mean of 3.855. Majority of the respondents $(89 \%)$ agreed that the demand for loans is high than the supply with a mean of 4.403 . They further agreed $(90 \%)$ that the procedures for loan application and award encourage loan Uptake with a mean of 4.307.

In addition majority of the respondents (81\%) agreed that the group is able to make full payment of loan on time with a mean of 4.145 . Majority of the respondents $(88 \%)$ also agreed that group members are confident of taking up loans from (C-WES) with a mean 4.387. 


\begin{tabular}{|c|c|c|c|c|c|c|}
\hline \multicolumn{7}{|c|}{ Correlations } \\
\hline & & $\begin{array}{c}\text { Loan } \\
\text { repayment } \\
\text { policies }\end{array}$ & $\begin{array}{c}\text { Financial } \\
\text { Literacy }\end{array}$ & $\begin{array}{l}\text { Lending } \\
\text { procedures }\end{array}$ & $\begin{array}{c}\text { Financial } \\
\text { Characteristics }\end{array}$ & $\begin{array}{c}\text { Micro-loan } \\
\text { uptake }\end{array}$ \\
\hline \multirow{2}{*}{$\begin{array}{l}\text { Loan repayment } \\
\text { policies }\end{array}$} & $\begin{array}{l}\text { Pearson } \\
\text { Correlation }\end{array}$ & 1 & .068 & .109 & $.155^{*}$ & $.441^{* *}$ \\
\hline & $\begin{array}{l}\text { Sig. (2-tailed) } \\
\text { N }\end{array}$ & 62 & $\begin{array}{c}.265 \\
62\end{array}$ & $\begin{array}{c}.071 \\
62\end{array}$ & $\begin{array}{l}.010 \\
62\end{array}$ & $\begin{array}{l}.000 \\
62\end{array}$ \\
\hline \multirow{2}{*}{ Financial Literacy } & $\begin{array}{l}\text { Pearson } \\
\text { Correlation }\end{array}$ & .068 & 1 & .076 & .035 & .430 \\
\hline & $\begin{array}{l}\text { Sig. (2-tailed) } \\
\mathrm{N}\end{array}$ & $\begin{array}{l}.265 \\
62\end{array}$ & 62 & $\begin{array}{c}.208 \\
62\end{array}$ & $\begin{array}{l}.566 \\
62\end{array}$ & $\begin{array}{c}.022 \\
62\end{array}$ \\
\hline \multirow{2}{*}{$\begin{array}{l}\text { Lending } \\
\text { procedures }\end{array}$} & $\begin{array}{l}\text { Pearson } \\
\text { Correlation }\end{array}$ & 109 & .076 & 1 & $.232^{* *}$ & $.441^{*}$ \\
\hline & $\begin{array}{l}\text { Sig. (2-tailed) } \\
\mathrm{N}\end{array}$ & $\begin{array}{c}.041 \\
62 \\
\end{array}$ & $\begin{array}{c}.008 \\
62 \\
\end{array}$ & 62 & $\begin{array}{l}.000 \\
62 \\
\end{array}$ & $\begin{array}{l}.006 \\
62 \\
\end{array}$ \\
\hline \multirow{2}{*}{$\begin{array}{l}\text { Financial } \\
\text { Characteristics }\end{array}$} & $\begin{array}{l}\text { Pearson } \\
\text { Correlation }\end{array}$ & $.155^{*}$ & .035 & $.232^{* *}$ & 1 & $.443^{* *}$ \\
\hline & $\begin{array}{l}\text { Sig. (2-tailed) } \\
\mathrm{N}\end{array}$ & $\begin{array}{l}.010 \\
62\end{array}$ & $\begin{array}{l}.016 \\
62\end{array}$ & $\begin{array}{l}.000 \\
62\end{array}$ & 62 & $\begin{array}{l}.000 \\
62\end{array}$ \\
\hline \multirow{2}{*}{ Micro-loan uptake } & $\begin{array}{l}\text { Pearson } \\
\text { Correlation }\end{array}$ & $.441^{* *}$ & .430 & $.441^{*}$ & $.443^{* *}$ & 1 \\
\hline & $\begin{array}{l}\text { Sig. (2-tailed) } \\
\mathrm{N}\end{array}$ & $\begin{array}{l}.000 \\
62\end{array}$ & $\begin{array}{l}.022 \\
62\end{array}$ & $\begin{array}{l}.006 \\
62\end{array}$ & $\begin{array}{l}.000 \\
62\end{array}$ & 62 \\
\hline
\end{tabular}

*. Correlation is significant at the 0.05 level (2-tailed).

The findings indicated that there was a moderate positive and statistically significant correlation between financial characteristics and micro-loan uptake. $(r=0.443 ; p<0.05)$. These findings are consistent with the reviewed literature where Tagoe, Nyarko, and Anuwa-Amarh (2015) found out that good information management and the ability to use information to present a well-crafted business case for financing reduced risk perception and increased the chance of SMEs getting adequate funds. Therefore, SME's should seek to improve their information management practices and investor relations skills to improve their access to credit.

The findings indicated that there was a moderate positive and statistically significant correlation between lending procedures and micro-loan uptake. $(\mathrm{r}=0.441 ; \mathrm{p}<0.05)$. This implies that better lending procedures results to an increase in micro-loan uptake at Nakuru East Constituency. Thus the finding of the study empirically confirms the perspective that lending procedures influence the uptake of micro-loans at Nakuru East Constituency Women Enterprise Scheme amongst women entrepreneurs. This agrees with Sabato, (2010) who found out that the nature of problems reported by women group were related to issues of the application process for debt finance in financial institutions.

The findings indicated that there was a moderate positive and statistically significant correlation between financial literacy and micro-loan uptake. $(r=0.430 ; \mathrm{p}<0.05)$. Financial literacy helps individuals to improve their level of understanding of financial matters which enables them to process financial information and make informed decisions about one's finances (Puneet, 2014). A lack of financial literacy is problematic if it renders individuals unable to optimize their own welfare, especially when the stakes are high, or to exert the type of competitive pressure necessary for market efficiency.

The findings indicated that there was a moderate positive and statistically significant correlation between loan repayment policies and micro-loan uptake. $(\mathrm{r}=0.441 ; \mathrm{p}<0.05)$. The findings of the study agrees with Andrew (2014) who argued that strict loan repayment policies the uptake of loans is affected since potential borrowers feel uncomfortable with the amount lent

\section{Multiple Regression Results}

The study ascertained the influence of financial characteristics, lending procedures, and financial literacy and loan repayment policies on micro-loan uptake at Nakuru East Constituency Women Enterprise Scheme amongst women entrepreneurs. The results in relation to the foregoing are illustrated in Tables 4.17 


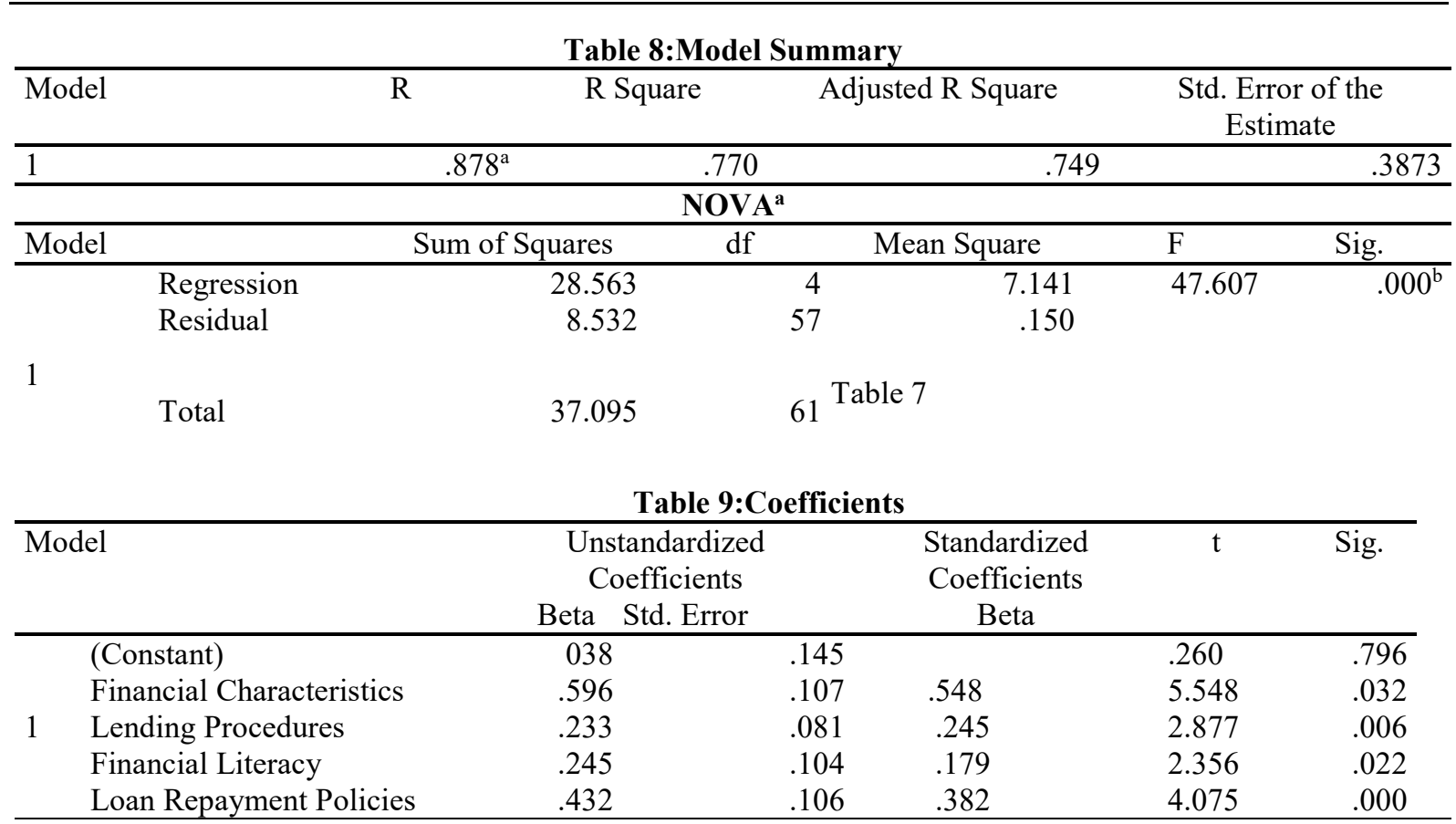

a. Predictors: (Constant), Financial Characteristics, Lending Procedures, Financial Literacy and Loan Repayment Policies

b. Dependent Variable: Micro loans uptake at the Nakuru East Constituency Women Enterprise Scheme

The model in Table 8 shows factors determining Micro loans uptake at the Nakuru East Constituency Women Enterprise Scheme. The Model shows that R Square is .770, which shows that $77.0 \%$ of the variation in Micro loans uptake at the Nakuru East Constituency Women Enterprise Scheme is explained by financial characteristics, lending procedures, financial literacy and loan repayment policies.

The ANOVA demonstrates test for the combined influence of financial characteristics, lending procedures, and financial literacy and loan repayment policies on micro-loan uptake by women enterprise groups in Nakuru East Constituency, Nakuru County. The ANOVA results show that the model was significant $(\mathrm{F}=47.607, p<$ 0.05). This indicates that the combined influence of financial characteristics, lending procedures, financial literacy and loan repayment policies have a positive significant effect on micro-loan uptake by women enterprise groups in Nakuru East Constituency, Nakuru County.

The full regression model in Table 9 was also interpreted to show how determining factors influence on micro-loan uptake by women enterprise groups in Nakuru East Constituency, Nakuru County. The unstandardized coefficients show that for every unit increase in financial characteristics, a 0.596 unit increase in on micro-loan uptake by women enterprise groups is predicted holding other variables constant. For every unit increase in lending procedures, a 0.233 unit increase in on micro-loan uptake by women enterprise groups in Nakuru East Constituency, Nakuru County is predicted holding other variables constant. For every unit increase in financial literacy, a 0.254 unit increase in on micro-loan uptake by women enterprise groups in Nakuru East Constituency, Nakuru County is predicted holding other variables constant. Finally for every unit increase in loan repayment policies, a 0.432 unit increase in Micro loans uptake at the Nakuru East.The interpretations of the findings indicated follow the following regression model.

$Y=\alpha+\beta_{1} X_{1}+\beta_{2} X_{2}+\beta_{3} X_{3}+\beta_{4} X_{4}$

Therefore,

$\mathrm{Y}=0.038+0.596 \mathrm{X}_{1}+0.233 \mathrm{X}_{2}+0.245 \mathrm{X}_{3}+0.432 \mathrm{X}_{4}$

The hypothesis was H01: Financial characteristics has no significance influence on uptake of micro-loans by women enterprise groups in Nakuru East Constituency, Nakuru County. From the test, the result presented in Table 4.17 were $\mathrm{t}=5.548$ and $\mathrm{p}=0.032(<0.05)$. The findings indicated that financial characteristics has a significance influence on uptake of micro-loans at Nakuru East Constituency Women Enterprise Scheme amongst women entrepreneurs, the first null hypothesis was therefore rejected and conclusion made that financial characteristics has a significance influence on uptake of micro-loans by women enterprise groups in Nakuru East Constituency, Nakuru County

The hypothesis was $\mathrm{HO}_{2}$ : Lending procedures has no significance influence on uptake of micro-loans by women enterprise groups in Nakuru East Constituency, Nakuru County. From the test, the result presented in Table 4.17 were $\mathrm{t}=2.877$ and $\mathrm{p}=0.006(<0.05)$. The findings indicated that lending procedures has a significance influence on uptake of micro-loans by women enterprise groups in Nakuru East Constituency, Nakuru County, the second 
null hypothesis was therefore rejected and conclusion made that lending procedures has a significance influence on uptake of micro-loans by women enterprise groups in Nakuru East Constituency, Nakuru County.

The hypothesis was $\mathrm{H}_{3}$ : Financial literacy has no significance influence on uptake of loans by women enterprise groups in Nakuru East Constituency, Nakuru County. From the test, the result presented in Table 4.17 were $\mathrm{t}=2.356$ and $\mathrm{p}=0.022(<0.05)$. The findings indicated that financial literacy has a significance influence on uptake of micro-loans by women enterprise groups in Nakuru East Constituency, Nakuru County, the third nullhypothesis was therefore rejected and conclusion made that financial literacy has a significance influence on uptake of micro-loans by women enterprise groups in Nakuru East Constituency, Nakuru County.

The hypothesis was $\mathrm{H}_{4}$ : Loan repayment policies has no significance influence on uptake of loans by women enterprise groups in Nakuru East Constituency, Nakuru County. From the test, the result presented in Table 4.17 were $\mathrm{t}=4.075$ and $\mathrm{p}=0.000(<0.05)$. The findings indicated that loan repayment policies has a significance influence on uptake of micro-loans by women enterprise groups in Nakuru East Constituency, Nakuru County, the forth hypothesis was therefore rejected and conclusion made that loan repayment policies has a significance influence on uptake of micro-loans by women enterprise groups in Nakuru East Constituency, Nakuru County.

\section{Conclusions}

From the findings the researcher concluded that the group maintains and keeps a list of their assets and liabilities. The study also concluded that majority of the group do not have a monthly and a yearly budget that they follow. Majority of groups are not in a capacity to maintain all their financial records on income and expenditure.

In relation to the second objective, it was concluded that the group must achieve a particular number of members before borrowing. The number of group members determines the amount of loan issued. The researcher also concluded that there are well defined limits on the maximum amount of loan that a group can borrow. For a loan to be issued the group must have existed for more than 5 years. Majority of group had tried to get a loan in the last 12 months. Majority of loan applications are processed within a period of 1-2 months. Finally the research concluded that loan applications take 2-3 months before a decision is made on whether they are successful.

Concerning the third objective, it can be concluded that lack of awareness on funding opportunities has led to poor access to credit by Women Group. Majority of group members lack awareness of existing credit schemes. The researcher further concluded that majority of group members lack information on interest rates of various credit schemes. From the findings the research concluded that majority of the respondents stated they had not attended any form of training on financial management.

From the fourth objectives it can be concluded that women group consider interest rated before borrowing. A less liquid security attracts high interest rate. Interests on loans vary depending on length of time to maturity. Finally the findings concluded that the group considers the penalties for loan default before taking loan.

\section{REFERENCES}

Ackerly, B. (2015). "Testing the tools of Development; Credit Programmes. Loan Involvement, and Women's Empowerment" South African Journal of Economics, 73(1), 54-67.

Admassie, A. \& Amha, W. (2008). Public Private Partnership Projects of the GTZ in Ethiopia: International Trade and the protection of Natural resources in Ethiopia. Bonn: Eschoborn.

Andrew, F. (2014). District councils fail to issue over 46bn/- in loan Money for youth, women projects. The Guardian, No. 6295

Beck, J., \& Honohon F. (2008). Formal and Informal Rural Credit in Four Provinces of Vietnam. Discussion Papers, Department of Economics, University of Copenhagen.

Borode, M. (2014). Empowering women through credit facilities for sustainable development in the developing countries. International Journal of Vocational \& Technical 4(2), 56-74.

Bruni, F., Gherardi, T., \& Poggio, C. (2008). Access to external finance: Theory and evidence on Impact of monetary policy and firm-specific characteristics. Journal of Banking and Finance 34(34)1417-143.

CGAP, (2014). Scaling Up Poverty Reduction: Case Study for Microfinance. World Bank Financial Sector Network. Washington, D.C.

Chimucheka. T., \& Rungani, E. (2011). The impact of inaccessibility to bank finance and lack of financial management knowledge to small, medium and micro enterprises in Buffalo City Municipality. South Africa African Journal of Business Management 5(14), 5509-5517.

Kamau, J. \& Ngugi, J. (2009). Factors affecting the Growth of Small and Micro Enterprises Dairy Farmers in Kenya: Case of Gatundu South Farmer's Dairy Co-operative Society Ltd. International Journal of Current Business and Social Sciences, 1(1), 48-63.

Kilele, E. (2014). Incentives and Constraints of Financing Mechanisms for Compliance to Global GAP Standards among Smallholder Horticultural Farmers in Kenya.

KIPPRA. (2010). Transforming Institution for Delivery of Kenya Vision 2030. Nairobi Kenya. Kenya Economic Report: 2010. 
Kiraka, K. (2013). Determinants of loan Repayment Performance: A case study in the Addis Credit and Saving Institution, Addis Ababa, Ethiopia. Wageningen the Netherlands. Journal of Finance and Accounting, 7(2), $235-245$

Kombo, D., \& Tromp, L. (2009). Research methods: Nairobi Kenya: Kenyatta University Press.

Kothari, C. (2004). Research methodology: Methods and techniques. New Age

Luong, R., Malitz, J., \& Ravid, T. (2010). Regional Integration Procedures to Support Job Creation for Africa's Burgeoning Youth Population, ACBF Working Paper No.21, Zimbabwe

Madura, M. (2013). Microfinance Repayment Performance in Bangladesh: How to Improve the Allocation of Loans by MFIs. Journal of World Development, 32(11), 1909-1926.

Mahdzan, S., \& Tabiani, S. (2013). The Impact of Financial Literacy on Individual Saving:An Exploratory Study in the Malaysian Context. Journal in Business and Economics, 12(28), 41-55.

Makombe, I. (2009). Credit schemes and women's empowerment for poverty alleviation: the case of Tanga Region, Tanzania. International Journal of Management and Commerce Innovations 5(2), 177-187

Mandell, I. (2008). Women entrepreneurship development and empowerment in Tanzania: the case of SIDO/UNIDO-supported women micro entrepreneurs in the food processing sector. University of South Africa.

Mayouc, J. (2012). Good Practices in Building Innovative Rural Institutions to Increase Food Security. International Journal of Business and Management Invention, 15 (9), 05-08

MIX, A. (2015). Small business and the value of community financial Institutions. Journal of finance services research, 25(90), 207-230

Mole, G., \& Namusonge, J. (2016). 'SME Finance, Development and Trade. The Journal of Finance, 7(1), 77-91

Morduch, L. (2010). Credit demand in the Dhaka Slums. Journal of Development Economics, 3(45), 437-449.

Mugenda, O., \& Mugenda, A. (2003). Research Methods: Qualitative and Quantitative Approaches. Nairobi. Acts Press.

Okoho, T., \& Orebiyi, G. (2011).The policy Environment for Promoting Small and Medium Sized Enterprises in Ghana and Malawi, (Working Paper Series, Paper No 15). Manchester, England: University of Manchester, Department of Finance and Development Research

Omollo, B. (2016). Influence of Constituency Women Enterprise Scheme on the Economic Empowerment of Women Entrepreneurs in Kisumu Rural in Kenya. University of Nairobi. Journal of Finance, 32(2), 371-387.

Oxaal Z., \& Baden S. (2012). Gender and Empowerment: Definitions, Approaches \& Implications for Policy. Institute of Development Studies, University of Sussex Brighton, UK

Pandula, G. (2011). An Empirical Investigation of Small and Medium Enterprises' Access to bank finance: The Case of an Emerging Economy. International Journal of Economics and Research, 6(4), 23-29.

Paxton J. (2011). Determinants of Successful Loan Repayment: An Application to Burkina Faso. Paper Presented at Ohio State University, Ohio

Paxton, H. (2014). The Role of Social Capital to Access Credit; A Case Study of Dinh Cu and Van quat Dong Village in the Coastal area of Thuo Thien Hue Province. Hue University of Agriculture and Forestry, Vietman. Online publication

Pollinger, T., Outhwaite, F., \& Cordero, G., (2007), The Question of Sustainability for Microfinance Institutions. Journal of Small business Management 6(4), 23-29.

Sabato. G (2010). Assessing the Quality of Retail Customers: Credit Risk Scoring Models .The IUP Journal of Financial Risk Management, 4(7), 113 - 125.

Suberu, O., Aremu, O., \& Popoola, E. (2014). The impact of microfinance institutions on the development of small scale enterprises in Nigeria Journal of Research in International Business Management 1(8), $251-257$.

Suwanaphan, S. (2013). Personal Financial Litaracy of Academic Support: Employee in Chiang Mai University. International Conference, (19-21). Thailand.

Tagoe, N., Nyarko, E., \& Anuwa-Amarh, E. ( 2015). Financial Challenges Facing Urban SMEs under Financial Sector Liberalization in Ghana. Journal of Small Business Management 43(3), 331-343.

Thuranira , C. (2009) Factors affecting accessibility of credit facilities among the small and micro-enterprises Nairobi, Kenya. Asian Journal of Business Management 3(3), 178-187.

World Bank (2011). Engendering Development Through Gender Equality in Rights, Resources and Voice. Oxford University Press, New York.

World Bank. (2007). Engendering Development: Through Gender Equality in Rights, Resources, and Voice. World Bank Policy Research Report. Oxford: Oxford University Press

World Bank. (2008). Youth Development; Youth Entrepreneurship Volume II, Number 6, Oxford University Press, New York.

Xiong, T., \& Xiong, Y. (2010). The significance of psychology and environment dimensions for Malaysian Muslim Women Entrepreneurships venturing. International Journal of Human sciences, 7(1), 253-269 